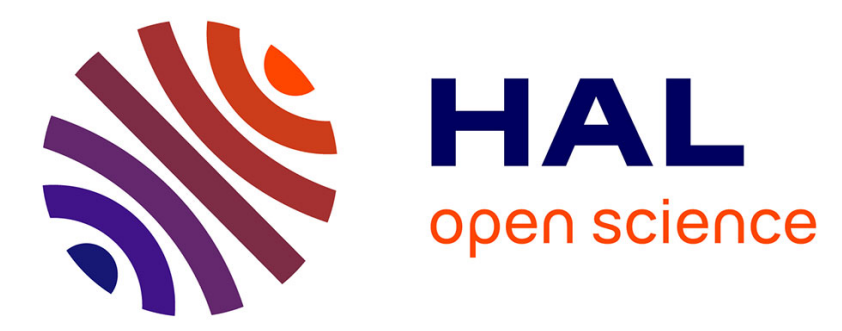

\title{
Carbonatite Melts and Electrical Conductivity in the Asthenosphere
}

Fabrice Gaillard, Mohammed Malki, Giada Iacono-Marziano, Michel Pichavant, Bruno Scaillet

\section{- To cite this version:}

Fabrice Gaillard, Mohammed Malki, Giada Iacono-Marziano, Michel Pichavant, Bruno Scaillet. Carbonatite Melts and Electrical Conductivity in the Asthenosphere. Science, 2008, 322 (5906), pp.1363 - 1365. 10.1126/science.1164446 . insu-00343685

\section{HAL Id: insu-00343685 https://hal-insu.archives-ouvertes.fr/insu-00343685}

Submitted on 2 Jan 2009

HAL is a multi-disciplinary open access archive for the deposit and dissemination of scientific research documents, whether they are published or not. The documents may come from teaching and research institutions in France or abroad, or from public or private research centers.
L'archive ouverte pluridisciplinaire HAL, est destinée au dépôt et à la diffusion de documents scientifiques de niveau recherche, publiés ou non, émanant des établissements d'enseignement et de recherche français ou étrangers, des laboratoires publics ou privés. 


\title{
SMALl AMOUNT OF CARBONATITE MELTS EXPlains HIGH ELECTRICAL CONDUCTIVITY IN THE ASTHENOSPHERE
}

\author{
Gaillard $\mathrm{F}^{1}$, Malki $\mathrm{M}^{2}$, Iacono-Marziano $\mathrm{G}^{1}$, Pichavant $\mathrm{M}^{1}$, Scaillet $\mathrm{B}^{1}$ \\ ${ }^{1}$ Corresponding author: gaillard@cnrs-orleans.fr \\ CNRS/INSU, Université d'Orléans, Université François Rabelais - Tours, \\ Institut des Sciences de la Terre d'Orléans - UMR 6113 \\ Campus Géosciences, 1A, rue de la Férollerie, 41071 Orléans cedex 2, France. \\ 2 CEMHTI-CNRS, UPR3079, 1D avenue de la Recherche Scientifique, 45071 Orléans cedex2, \\ France. \\ ${ }^{2}$ Polytech’Orléans - Université d’Orléans, 8 rue Léonard de Vinci, 45072 Orléans cedex 2, France.
}

\section{One sentence summary:}

We unambiguously show that molten carbonates have electrical conductivities exceeding by far the one of any mantle phases. We therefore propose that mantle electrical anomalies observed by geophysical surveys image the presence at depth of small quantities of molten carbonates providing us the possibility to better constrain the distribution of carbon in the deep Earth. 
Abstract: (140 words)

Electrically conductive regions in the Earth mantle are classically interpreted to reflect the presence at depth of either molten silicates or water dissolved in olivine. However, geochemical studies have largely recognized molten carbonates as important fluid agents in the mantle, but their impact on the electrical properties of the mantle has never been evaluated. Laboratory measurements reported here show that molten carbonates have electrical conductivities exceeding by 3 orders of magnitude those of molten silicate and by 5 orders of magnitude those of hydrated olivine. Many conductive regions of the mantle can thus reflect the presence of small amounts of pervasive molten carbonates, which are thermodynamically stable in the upper mantle. In particular, the deep conductive oceanic asthenosphere can be explained by 30$460 \mathrm{ppm} \mathrm{CO}_{2}$ in the form of molten carbonates, consistent with estimated $\mathrm{CO}_{2}$ fluxes at mid ocean ridges. 
Laboratory measurements on anhydrous peridotite and olivine single crystals indicate that the electrical conductivity of the upper mantle, if dry, should be in the range $10^{-4}-10^{-2} \mathrm{~S}^{-\mathrm{m}^{-1}}$ with high conductivity values essentially reflecting high mantle temperatures $(1,2)$. Deep magnetotelluric sounding however indicates that the electrical conductivity of some mantle regions exceeds those

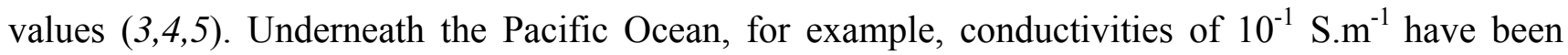
clearly recognized deeper than $60 \mathrm{~km}$ (5). Such zones require the presence at depth of conductive phases; silicate melts or hydrated olivine crystals are commonly considered $(3,5,6,7)$. Silicate melts have electrical conductivity in the range $10^{-2}-10$ S.m ${ }^{-1}(6,8,9)$ but can only be present if the temperature of the mantle is high enough to allow peridotite melting (10). Incorporation of trace amounts of hydrogen in olivine is therefore the most accepted way to interpret high mantle conductivity $(4,5,7,11)$. Direct measurements in mantle xenoliths indeed provide compelling evidence for hydrated mantle olivine (12), however, the magnitude of the effect of water on olivine conductivity remains under debate $(13,14)$. Furthermore, measurements performed on hydrated single olivine crystals cannot explain high electrical anisotropy in the asthenospheric mantle (14). We present here molten carbonates (i.e. carbonatites) as an additional phase potentially explaining high conductivity in the mantle. Hereafter, we review the petrological supports for their presence and stability in the mantle and report laboratory evidence of their very high electrical conductivity. We conclude that mantle regions with high conductivity probably image the presence of small amounts of carbonatite melts, in keeping with geochemical observations.

Carbonatites are very rare at the Earth surface and only one volcano, Ol Doinyo Lengai, Tanzania, is currently emitting such magmas (15). The reason classically put forward to explain such a scarcity is that these carbonate melts, initially present in the mantle, are diluted and masked by silicate melts that constitute the overwhelming part of extrusive rocks at the Earth surface (16). The carbon dioxide content of mantle derived magmas is in the range of a few hundredth ppm in mid ocean ridge basalts and can reach a few thousand ppm in specific settings $(17,18)$, which constrains the $\mathrm{CO}_{2}$ content of the mantle source to a few tens to hundreds ppm $(17,18)$. Under most of the P-T-redox conditions 
prevailing in the upper mantle, carbon is likely to be present in the form of molten carbonates (1921). Such carbonatite melts have exceedingly large wetting properties (22): they form interconnected liquid networks at olivine grain boundaries even at very low volume fractions $(22,23)$ and could therefore contribute to the electrical conductivity of the mantle. The available data on the electrical conductivity of molten carbonates cover Li-rich compositions of industrial interest (24). However, mantle carbonatites are particularly Li-poor and $\mathrm{Mg}$, Ca-rich with $\mathrm{K}$ and $\mathrm{Na}$ in variable proportions (25). In this paper, we extend the database on electrical conductivity of molten carbonates to Li-free and Ca-rich system. The measurements were performed at 1 atmosphere of $\mathrm{CO}_{2}$ pressure using a 4electrode experimental method specifically adapted to greatly conductive molten materials (26; see Note and Supporting online material, SOM). No magnesium carbonate was included in our material because Mg-bearing molten carbonates are not stable at 1 atm pressure and the very high conductivities of carbonate melts shown below makes the deployment conductivity measurements with conventional setup very challenging at high pressure. Potential pressure effects are nevertheless revealed below to be probably minor.

The electrical conductivity of molten carbonate compositions measured here increases from 50 to 200 $\mathrm{S} . \mathrm{m}^{-1}$ for temperature increasing from 400 to $1000^{\circ} \mathrm{C}$ (Table $\left.1, \mathrm{SOM}\right)$. Such conductivity values are comparable to those reported on Li-rich molten carbonates (24, SOM). In Figure 1, we show the temperature dependence of molten carbonate electrical conductivity together with the one of other mantle phases such as dry and hydrous olivine $(2,13,14)$ and silicate melts $(6,8,9)$. Molten carbonates at $1000^{\circ} \mathrm{C}$ are 1000 times more conductive than molten silicates at the same temperature and 100,000 times more conductive than hydrous olivine single crystals. Our measurements show that the electrical conductivity of molten carbonates varies slightly with their chemical composition. Calciumfree carbonates containing $30 \% \mathrm{Li}_{2} \mathrm{CO}_{3}$ is only about 2 to 3 times more conductive than a $\mathrm{Li}$-free melt containing $50 \%$ of $\mathrm{CaCO}_{3}$ (Fig. 1, Table 1, see also SOM). Another striking feature of molten carbonate conductivities is their small temperature dependence. The temperature dependence of molten carbonate electrical conductivities $(\sigma)$ can be adequately fitted using an Arrhenius law: 
$\sigma=\sigma_{0} \times \exp [-\mathrm{Ea} /(\mathrm{RT})]$

The fitted pre-exponential terms $\left(\sigma_{0}\right)$ and the activation energies (Ea) for each investigated composition are listed in Table 1 . Activation energies are in the range $30-35 \mathrm{~kJ} / \mathrm{mol}$, which is about one third of the average activation energies for the electrical conductivity of natural molten silicates $(70-150 \mathrm{~kJ} / \mathrm{mol} ; 6,8,9)$ and one tenth of those of dry olivine $(200-400 \mathrm{~kJ} / \mathrm{mol} ; 2)$. Such low activation energies are very similar to those of $\sim 38 \mathrm{~kJ} / \mathrm{mol}$ reported by (27) for the viscosity of synthetic molten carbonates of composition $\left(\mathrm{K}_{2} \mathrm{Ca}\right)\left(\mathrm{CO}_{3}\right)_{2}$. Furthermore, we calculated (see details in the $\mathrm{SOM}$ ) that the diffusing process responsible for the electrical conductivity and the viscosity of molten $\left(\mathrm{K}_{2} \mathrm{Ca}\right)\left(\mathrm{CO}_{3}\right)_{2}$ are similar $\left(\sim 10^{-9} \mathrm{~m}^{2} \cdot \mathrm{s}^{-1}\right.$ at $\left.1000^{\circ} \mathrm{C}\right)$. This very likely indicates that, on the contrary to silicate melts $(8,9)$, both viscosity and electrical conductivity of carbonate melts entail similar transport mechanisms. Extrapolation to mantle conditions requires an evaluation of the effect of $\mathrm{MgCO}_{3}$ addition (mantle carbonatites are supposed to contain 10-15wt\% $\mathrm{MgO}$ at equilibrium with mantle minerals (25)) and of pressure, which in view of the similarities between conductivity and viscosity transport mechanisms noted above, can be deduced from the effect of magnesium and pressure on the viscosity of molten carbonates. Magnesium-bearing molten carbonates have been shown to be slightly less viscous relatively to those Mg-free (27). We therefore expect the conductivity of Mg-bearing carbonatites to be slightly higher and anyway close to those of $\mathrm{Mg}$-free molten carbonates measured here (see calculations in SOM). Since no pressure effect on the viscosity of molten carbonates has been suggested by experimental methods (27) and by molecular dynamics calculations (28), we conclude that molten carbonates should preserve the very high conductivity we determined here at 1 bar up to mantle pressures (see SOM). The electrical conductivity of mantle carbonatites can therefore reasonably be described by the Arrhenius equation given in Table 1.

Molten carbonates are therefore by far the most conductive phase of the Earth upper mantle. Hereafter, we propose an interpretation of mantle electrical conductivity based on the laboratory measurements of conductivities of carbonatite melts and olivine (the latter representing mantle peridotite, (2)). We focus on the asthenosphere below the pacific oceanic crust because (i) this region 
of the mantle is relatively well constraints by the MELT geophysical imaging $(4,5)$ and (ii) recent petrological evidence suggests that small quantities of carbonatites liquids are formed in such astenospheric mantle at depth up to $\sim 300 \mathrm{~km}(16,19)$. The MELT geophysical surveys imaged a resistive body $\left.\left(\sigma \sim 10^{-2}-10^{-3} \mathrm{~S}^{-1}\right)^{-1}\right)$ consistent with anhydrous peridotite in the upper $60 \mathrm{~km}(5)$. A conductive structure $\left(\sigma \sim 10^{-1} \mathrm{~S} . \mathrm{m}^{-1}\right)$ extending down to $200 \mathrm{~km}$ below the ridge axis has been detected (5). A structure of nearly comparable conductivity in the direction perpendicular to the ridge axis was also observed on the East side of the ridge at depth between 60 and $150 \mathrm{~km}$ (5). Given that hydrated single olivine crystals cannot account for the conductivities observed at $60-120 \mathrm{~km}$ depth and for their anisotropic structures (14), an additional conductive component at 70-200 km depth is needed. Petrological constraints indicate that melting of silicate is insignificant at depth exceeding $70 \mathrm{~km}$ $(10,16)$ while carbonatite melts are stable down to $\sim 300 \mathrm{~km}(19)$. Figure 2 shows the calculated range of electrical conductivity and resistivity of a mantle at $\mathrm{T}=1400^{\circ} \mathrm{C}$ constituted of dry and hydrous olivine mixed with variable melt fractions. The dashed curve represents a dry olivine assemblage with of MOR-Basalt (6) whereas the full lines represent assemblages of dry and hydrated olivine with carbonatite melts. Small amounts of interconnected $(22,23)$ carbonatite melts $(0.01$ to 0.1 vol.\%) added to a peridotite substantially increase its conductivity regardless of the hydrated or dry character of the olivine. According to the experimental constraints on mantle melting processes below mid ocean ridges $(16,19)$, carbonatites melts are likely to be the first melts formed at pressures exceeding $2 \mathrm{GPa}$, followed by silicate melts at lower pressures $(10,16)$. Mantle electrical conductivities at depth $>70 \mathrm{~km}$ would therefore follow the full lines in Fig.2 (a peridotite containing trace amounts of carbonatite melts) while at shallower depths, they would follow the dashed lines (a peridotite containing variable amounts of silicate melts). The transition from carbonatite-dominated to silicatedominated melts should occur at $\sim 70 \mathrm{~km}$ depth (10-16). The dotted line in Figure 2 illustrates the progressive changes in electrical conductivity during partial melting of a peridotite containing 50, 120 and $1200 \mathrm{ppm} \mathrm{CO}_{2}$ as carbonatite melts (using density from (29)). The transition carbonate- 
dominated to silicate-dominated partial melts possibly causes a maximum in conductivity at low melt fraction because silicate melts are much less conductive than carbonatite melts.

Figure 2 also shows that a conductivity of $\sim 0.5 \mathrm{~S} . \mathrm{m}^{-1}$, which corresponds to the highest conductivity so far detected below mid-ocean ridges at 170-200 $\mathrm{km}$ depths $(4,5)$, could be explained by a peridotite (whether dry or hydrated) containing $\sim 0.15$ volume percent of carbonatite melt. Very small fractions of carbonatite are therefore able to explain the most elevated electrical conductivity of the asthenospheric mantle imaged beneath mid-ocean ridges. Carbonatite volume percent of $\sim 0.15$ in a peridotite corresponds to $\sim 460 \mathrm{ppm} \mathrm{CO}_{2}$ content (using density from (29)), which matches well the variable estimates of $\mathrm{CO}_{2}$ content in the oceanic astenosphere (120-1,200 ppm) determined from $\mathrm{CO}_{2}$ fluxes at mid oceanic ridges $(17,18)$. However, significant vertical and lateral changes in the conductivity of the oceanic asthenosphere $\left(0.03-0.5 \mathrm{~S} . \mathrm{m}^{-1}\right)$ are reported at the scale of several tens of kilometers (5) as indicated by the orange area in figure 2. Such conductivity variations suggest changes in the carbonatite volume percents from 0.01 to 0.15 , which is equivalent to 30 to $460 \mathrm{ppm}$ $\mathrm{CO}_{2}$. Furthermore, (5) also reported electrical anisotropies of the oceanic asthenosphere that could reveal an anisotropic interconnection of very small amount of carbonatite melts by analogy with experimental observations on deformed peridotites containing small amounts of silicate melt (30). A quantification of the average $\mathrm{CO}_{2}$ content of the mantle, by means of its electrical conductivity, should therefore account for the heterogeneities and the anisotropies in electrical conductivity. We can nevertheless anticipate that the mantle electrical conductivity is extremely sensitive to tiny amounts of carbonatite melts, making this physical parameter a powerful probe of the carbon content in the mantle, as well as of its regional variations. We finally stress that our interpretations do not require large amounts of carbon in the mantle, since only a few tens ppm carbon in the form of carbonatite melts can account for conductivity anomalies in the asthenosphere. 
Note:

A four-electrode setup is shown in the SOM to be indispensable to properly determine the frequency dependence of molten carbonate impedance. Measurements were performed at room pressure and under $\mathrm{CO} 2$ atmosphere at temperatures up to $1000^{\circ} \mathrm{C}$. Samples were synthesized from mixtures of LiNa-K-Ca carbonate powders. A batch of 30 grams of sample was melted $100-200^{\circ} \mathrm{C}$ above the theoretical liquidus of the considered composition for 10 minutes in $\mathrm{Al}_{2} \mathrm{O}_{3}$ crucibles. At the same temperature and under $\mathrm{CO} 2$ flux, the 4-electrode assemblage was moved down in the furnace until they entered in the contact with the liquid surface, which was detected by an increase in conductivity. From this reference position, the electrodes were progressively immersed in the liquid to a depth of 8 $\mathrm{mm}$, which is shown in the SOM to be sufficient to constrain well the geometrical factor needed to convert electrical resistance to electrical conductivity. 
Figure captions:

Figure 1. Electrical conductivity versus temperature for the principal mantle phases (Dry and hydrated olivine, silicate melts, and carbonatite melts). SO3 refers to the model of anhydrous olivine conductivity (2). The hydrous olivine area shows both dataset of (13) and (14). The data of (14) on oriented single olivine crystals containing 100-200 ppm water are the two curves showing the lowest conductivity in the hydrous olivine field (labeled Yo). The two curves show crystallographic directions having the fastest and the slowest conduction. The upper hydrous olivine curve labeled (W) refers to the data of (13) for olivine aggregates with $100 \mathrm{ppm}$ water dissolved in olivine. For silicate melts, we show anhydrous in red and hydrated melts in blue. From the less to the more conductive we show (a) dry MOR-basalt at 2 GPa (6), (b) dry MOR-basalt at 1 bar (6), (c) dry alkali basalt at 1 bar (9), (d) Hydrous silica-rich melt at 1 bar (8) and (e) hydrous alkali basalts at 1 bar (9). Molten carbonates, on the upper part of the diagram, refer to the measurements performed in this work (see $\mathrm{SOM})$. From the less to the more conductive, we show $\left(\mathrm{KCa}_{0.5}\right)_{2}\left(\mathrm{CO}_{3}\right)_{2}$ referred as $(\mathrm{K}, \mathrm{Ca})$, $\left(\mathrm{NaKCa}_{0.5}\right)_{2}\left(\mathrm{CO}_{3}\right)_{3}$ referred as $(\mathrm{Na}, \mathrm{K}, \mathrm{Ca}),(\mathrm{NaK})_{2}\left(\mathrm{CO}_{3}\right)_{2}$ referred as $(\mathrm{Na}, \mathrm{K})$, and $(\mathrm{LiNaK})_{2}\left(\mathrm{CO}_{3}\right)_{3}$ referred as $(\mathrm{Li}, \mathrm{Na}, \mathrm{K})$. The conductivity of mantle carbonatite melts (Table 1 ) is estimated to be positioned between the $(\mathrm{K}, \mathrm{Ca})$ and $(\mathrm{Na}, \mathrm{K})$ curves. For clarity, the composition $(\mathrm{NaKCa})\left(\mathrm{CO}_{3}\right)_{2}$, listed in table 1 , is not shown here but is available in the SOM.

Figure 2. Calculated resistivity and conductivity of olivine-melt mixtures at $1400^{\circ} \mathrm{C}$. We assume here a Hashin-Shtrikman upper bound that implies an interconnected melt between olivine grains independently of the melt percentage. Dry and hydrous olivine crystals are considered: the dry olivine conductivity is calculated from the SO3 model (2) and the one of hydrous olivine is calculated after (14) for crystals containing 200 ppm water (average between fast and slow crystallographic axes). The olivine - MOR-basalt mixture (dashed line) is calculated considering the conductivity of dry basalt at 1 bar (6). The olivine - carbonatite mixture (full line) is calculated after the conductivity of mantle carbonatite given in Table 1. The dotted line represents the conductivity changes during the melting of a peridotite containing 50,120 and $1200 \mathrm{ppm} \mathrm{CO}$. Such curve follows the conductivity of an olivine-carbonatite mixture at small melt fraction and shifts to the one of an olivine-silicate melt mixture for higher melt fraction. The transition from carbonatite melts like conductivity to silicate melts like conductivity is shown abrupt (i.e. we assume that a MOR-basalt at 0.1 vol.\% of partial melting containing several wt $\%$ dissolved $\mathrm{CO} 2$ has electrical conductivities similar to those of dry MORB). The orange area shows the highly conductive asthenosphere underneath mid ocean ridge whereas the light-orange area shows the resistive lithosphere, which is compatible with the electrical conductivity of dry olivine (5). 
References:

1. Y. Xu, T. J. Shankland, B. T. Poe, Laboratory-based electrical conductivity in the Earth's mantle, J. Geophys. Res., 105, 27, 865-27,875 (2000)

2. S. Constable, SEO3: A new model of olivine electrical conductivity, Geophysical Journal International, 166, 435-437, (2006)

3. A.G. Jones, Imaging the continental upper mantle using electromagnetic methods. Lithos, 48, 5780, (1999)

4. R.L. Evans, G. Hirth, K. Baba, D. Forsyth , A. Chave, R. Mackie, Geophysical evidence from the MELT area for compositional controls on oceanic plates, Nature, 437, 249-252, (2005)

5. K. Baba , A.D. Chave, R.L. Evans, G. Hirth, R.L. Mackie Mantle dynamics beneath the East Pacific Rise at 17 degrees S: Insights from the Mantle Electromagnetic and Tomography (MELT) experiment. J. Geophys. Res.,111 B02101, (2006)

6. J. A. Tyburczy, H. S. Waff, Electrical conductivity of molten basalt and andesite to 25 kilobars pressure: Geophysical significance and implications for charge transport and melt structure, $J$. Geophys. Res., 88, 2413-2430, doi:10.1029/JB088iB03p02413, (1983)

7. S-I. Karato, Remote sensing of hydrogen in Earth's mantle. Water in Nominally Anhydrous Minerals, Book Series: Reviews in Mineralogy \& Geochemistry, 62, 343-376, (2006)

8. F. Gaillard, Laboratory measurements of electrical conductivity of hydrous and dry silicic melts under pressure, Earth Planet. Sci. Lett., 218, 215-228, doi:10.1016/S0012-821X(03)00639-3, (2004)

9. A Pommier, F. Gaillard, M. Pichavant, B. Scaillet, Laboratory measurements of electrical conductivities of hydrous and dry Mount Vesuvius melts under pressure, J. Geophys. Res., 113, B05205, doi:10.1029/2007JB005269, (2008)

10. M. M. Hirschmann, The mantle solidus: experimental constraints and the effect of peridotite composition. Geochem. Geophys. Geosyst. 1, 2000GC000070, (2000).

11. P. Tarits, S. Hautot, F. Perrier, Water in the mantle: Results from electrical conductivity beneath the French Alps. Geophys. Research Letters, 31, doi:10.1029/2003GL019277, (2004)

12. S. Demouchy, S.D. Jacobsen, F. Gaillard, C.R. Stern, Rapid magma ascent recorded by water diffusion profiles in mantle olivine, Geology, 34, 429-432, doi: 10.1130/G22386.1 (2006)

13. D.J. Wang, M. Mookherjee, Y.S. Xu, S-I. Karato, The effect of water on the electrical conductivity of olivine, Nature, 443, 977-980, (2006)

14. T. Yoshino, T. Matsuzaki, S. Yamashita, T. Katsura, Hydrous olivine unable to account for conductivity anomaly at the top of the asthenosphere. Nature, 443, 973-976, (2006) 
15. J.B. Dawson, J. Keller and C. Nyamweru, Historic and recent eruptive activity of Oldoinyo Lengai. In: K. Bell and J. Keller, Editors, Carbonatite Volcanism: Oldoinyo Lengai and the Petrogenesis of Natrocarbonatites, IAVCEI Proceedings in Volcanology, 4, Springer Verlag, Berlin, 4-22, (1995)

16. R. Dasgupta, M. M. Hirschmann, N.D. Smith, Water follows carbon: CO2 incites deep silicate melting and dehydration beneath mid-ocean ridges, Geology, v. 35; no. 2; p. 135-138; doi:10.1130/G22856A, (2007)

17. A.E. Saal , E.H. Hauri , C.H. Langmuir, M.R. Perfit, Vapour undersaturation in primitive midocean-ridge basalt and the volatile content of Earth's upper mantle, Nature, 419, 451-455 (2002).

18. P. Cartigny, F. Pineau, C. Aubaud, M. Javoy, Towards a consistent mantle carbon flux estimate: Insights from volatile systematics $\left(\mathrm{H}_{2} \mathrm{O} / \mathrm{Ce}, \delta \mathrm{D}, \mathrm{CO}_{2} / \mathrm{Nb}\right)$ in the North Atlantic mantle $\left(14^{\circ} \mathrm{N}\right.$ and $\left.34^{\circ} \mathrm{N}\right)$. Earth and Planetary Science Letters, 265, 672-685, (2008)

19. R. Dasgupta, M.M. Hirschmann, Melting in the Earth's deep upper mantle caused by carbon dioxide, Nature, 440, 659-661, (2006)

20. D.J. Frost, B.J. Wood, Experimental measurements of the fugacity of $\mathrm{CO}_{2}$ and graphite/diamond stability from 35 to $77 \mathrm{kbar}$ at 925 to $1650^{\circ} \mathrm{C}$, Geochim.Cosmochim. Acta 61, 1565-1574, (1997)

21. S.S. Shcheka, M. Wiedenbeck, D.J. Frost, H. Keppler, Carbon solubility in mantle minerals. Earth and Planetray Science Letters, 245, 730-742, (2006)

22. W.G. Minarik, E.B. Watson, Interconnectivity of carbonate melt at low melt fraction, Earth Planet. Sci. Lett., 133, 423-437, (1995)

23. T. Hammouda, D. Laporte, Ultrafast mantle impregnation by carbonatite melts. Geology, 28, 283-285, (2000)

24. T. Kojima , Y. Miyazaki , K. Nomura , K. Tanimoto, Density, surface tension, and electrical conductivity of ternary molten carbonate system $\mathrm{Li} 2 \mathrm{CO} 3-\mathrm{Na} 2 \mathrm{CO} 3-\mathrm{K} 2 \mathrm{CO} 3$ and methods for their estimation, Journal of the Electrochemical Society, 155, F150-F156, (2008)

25. R. J. Sweeney, Carbonatite melt compositions in the Earth's mantle, Earth and Planetary Science Letters, 128, 259-270, (1994)

26. C. Simonnet, J. Phalippou, M. Malki, A. Grandjean, Electrical conductivity measurements of oxides from molten state to glassy state, Review of Scientific Instruments, 74, 2085-2091 (2003)

27. D.P. Dobson, A.P. Jones, R. Rabe, T. Sekine, K. Kurita, T. Taniguchi, T. Kondo, T. Kato, O. Shimomura, S. Urakawa, In-situ measurement of viscosity and density of carbonate melts at high pressure, Earth Planet. Sci. Lett. 143, 207-215, (1996).

28. M. J. Genge, G.D. Price, A.P. Jones, Molecular dynamics simulations of CaCO3 melts to mantle pressures and temperatures: implications for carbonatite magmas. Earth and Planetary Letters, 131, 225-238, (1995) 
29. Q. Liu, R.A. Lange, New density measurements on carbonate liquids and the partial molar volume of the CaCO3 component. Contrib Mineral Petrol, 146, 370-381, (2003)

30. B.K. Holtzman, D.L. Kohlstedt, M.E. Zimmerman, F. Heidelbach, T. Hiraga , J. Hustoft, Melt segregation and strain partitioning: Implications for seismic anisotropy and mantle flow, Science, 301, 1227-1230, (2003) 
Figure

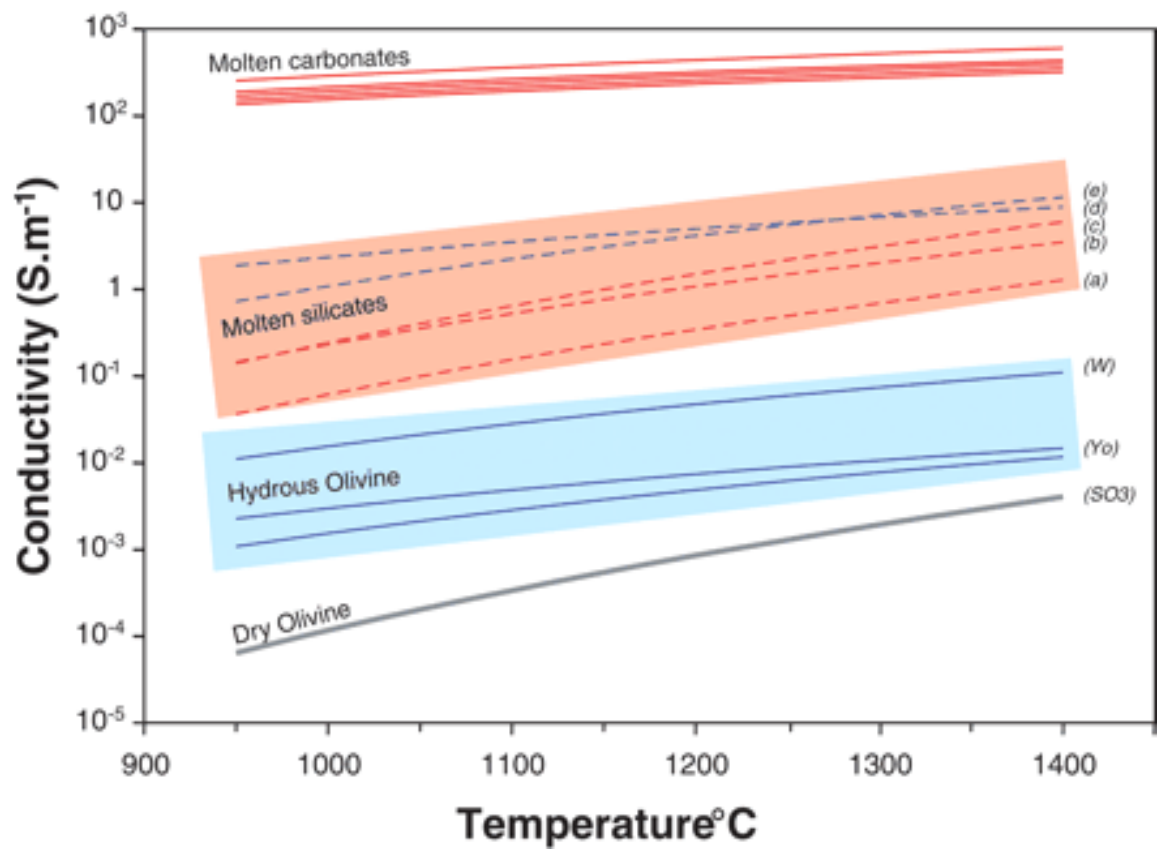

Fig. 1. Electrical conductivity versus temperature for the most important mantle phases (dry and hydrous olivine, molten silicates, and molten carbonates). SO3 refers to anhydrous olivine conductivity (2). For hydrous olivine, we show experimental data sets of $(14,15)$. The two curves labeled Yo, which exhibit the lowest conductivity in the hydrous olivine field, are on oriented single olivine crystals containing 100 to $150 \mathrm{ppmw}$ water (15). Each curve corresponds to crystallographic axes yielding the fastest and the slowest conduction. The upper curve labeled W refers to olivine aggregates with $100 \mathrm{ppmw}$ water dissolved in olivine (14). For silicate melts, anhydrous results are shown in red and hydrous in blue. From the less to the more conductive, results for (a) a dry MORB at 2 GPa (7), (b) a dry MORB at 1 bar (7), (c) a dry alkali basalt at 1 bar $(6,10)$, (d) a hydrous silica-rich melt at 1 bar (9), and (e) a hydrous alkali basalt at 1 bar (10) are shown. In the upper part of the diagram, the conductivities of molten carbonates are presented, extrapolated from our experiments at 400 to $1000^{\circ} \mathrm{C}$ using Eq. 1 (see fig. S8). From the less to the more conductive, we show $\left(\mathrm{KCa}_{0.5}\right)_{2}\left(\mathrm{CO}_{3}\right)_{2}$, $\left(\mathrm{NaKCa}_{0.5}\right)_{2}\left(\mathrm{CO}_{3}\right)_{3},(\mathrm{NaKCa})\left(\mathrm{CO}_{3}\right)_{2},(\mathrm{NaK})_{2}\left(\mathrm{CO}_{3}\right)_{2}$, and $(\mathrm{LiNaK})_{2}\left(\mathrm{CO}_{3}\right)_{3}$.

Table 1: Summary of experimentally defined parameter values for electrical conductivity of molten carbonates:

\begin{tabular}{lccc}
\hline Compositions & $\begin{array}{c}\sigma^{\circ} \\
\text { S.m } \\
( \pm 800)\end{array}$ & $\begin{array}{c}\text { Ea } \\
\text { J.mol } \\
( \pm 350)\end{array}$ & $\begin{array}{c}\sigma \text { at } \mathbf{1 0 0 0}^{-1} \mathbf{C} \\
{\mathrm{S} . m^{-1}}_{( \pm 15)}\end{array}$ \\
\hline$(\mathrm{LiNaK})_{2}\left(\mathrm{CO}_{3}\right)_{3}$ & 6590 & 32,500 & 305 \\
$(\mathrm{NaK})_{2}\left(\mathrm{CO}_{3}\right)_{2}$ & 4177 & 31,427 & 214 \\
$(\mathrm{NaKCa})_{0.5}\left(\mathrm{CO}_{3}\right)_{3}$ & 4144 & 32,500 & 192 \\
$(\mathrm{NaKCa})\left(\mathrm{CO}_{3}\right)_{2}$ & 2504 & 30,307 & 143 \\
$\left.(\mathrm{KCa})_{0.5}\right)_{2}\left(\mathrm{CO}_{3}\right)_{2}$ & 3149 & 34,489 & 121 \\
Mantle & & & \\
Carbonatites & 3442 & 31,892 & 169 \\
\hline
\end{tabular}

